\title{
Decreased chaperone activity of $\alpha$-crystallin in selenite cataract may result from selenite-induced aggregation
}

$\mathrm{H} \mathrm{Yan}^{1,2}$, JJ Harding ${ }^{2}$, YN Hui ${ }^{3}$ and MY Li ${ }^{4}$

\begin{abstract}
Purpose To investigate the role of chaperone activity of $\alpha$-crystallin in selenite-induced cataract formation.

Methods Selenite cataract was induced in Sprague-Dawley rats by five subcutaneous injections of sodium selenite over a 20-day period starting at 8-10 days postpartum. $\alpha$-Crystallin was separated from the rat lenses by size-exclusion chromatography. Bovine $\alpha_{\mathrm{L}}$-crystallin and $\beta_{\mathrm{L}}$-crystallin were isolated for studies in vitro, and for the chaperone assays. The protective effects of both $\alpha_{\mathrm{H}^{-}}$and $\alpha_{\mathrm{L}}$-crystallin were measured spectrophotometrically in four different assay procedures including the thermally induced aggregation of catalase and $\beta_{\mathrm{L}}$-crystallin, and the fructation- and heat-induced inactivation of catalase. The bovine $\alpha_{\mathrm{L}}$-crystallin was incubated with different concentrations of sodium selenite for $72 \mathrm{~h}$ and then its chaperone activity against heat-induced $\beta_{\mathrm{L}}$-crystallin aggregation was assayed. The aggregation of selenite-treated $\alpha_{L}$-crystallin was analysed by molecular sieve high-performance liquid chromatography (HPLC).
\end{abstract}

Results The protection of $\alpha_{\mathrm{H}}$-crystallin was less than that of $\alpha_{\mathrm{L}}$-crystallin in both normal and cataractous lenses. The chaperone activities of both $\alpha_{H^{-}}$and $\alpha_{\mathrm{L}}$-crystallin in selenite cataract were decreased compared with normal lenses. The protection provided by both $\alpha_{\mathrm{H}}$-crystallin and $\alpha_{\mathrm{L}}$-crystallin against the thermal aggregation of catalase was much greater than their protection against thermally and chemically induced inactivation. HPLC analysis demonstrated aggregation of $\alpha$-crystallin by sodium selenite after $24 \mathrm{~h}$ incubation in a dose-dependent fashion.
Conclusion The chaperone activity of $\alpha$-crystallin presented parallel patterns of activity with different methods, further supporting the view that the different assays measure essentially the same property. The decreased chaperone activity of $\alpha$-crystallin in selenite cataract may result from seleniteinduced aggregation.

Eye (2003) 17, 637-645. doi:10.1038/

sj.eye. 6700419

Keywords: molecular chaperone; $\alpha$-crystallin; selenite-induced cataract; catalase; aggregation

\section{Introduction}

The selenite-induced cataract produced in young rats has been used extensively as a model for nuclear cataract. Its reliability and reproducibility result in a good rodent model for testing potential anticataract drugs. ${ }^{1-6}$ Since Ostadalova et $a l^{7}$ first introduced this model, numerous experiments have shown that both a single $^{8-11}$ or repeated subcutaneous injections of smaller doses of selenite, ${ }^{12}$ and oral selenite administration $^{13}$ are cataractogenic. Selenite nuclear cataract appears within 3-5 days after a single injection of an overdose of sodium selenite. However, dense cortical cataract was also reported at 15-30 days after a single subcutaneous injection in addition to previously characterized nuclear changes, although it cleared subsequently. ${ }^{10}$

The major biochemical findings accompanying the development of selenite cataract include altered epithelial metabolism, calcium accumulation, calpain-induced proteolysis, crystallin precipitation, phase transition, and cytoskeletal loss..$^{2,14,15}$ The
${ }^{1}$ Department of Ophthalmology Tangdu Hospital The Fourth Military Medical University Xi'an, China

${ }^{2}$ Nuffield Laboratory of Ophthalmology University of Oxford Oxford, UK

${ }^{3}$ Institute of Ophthalmology Xijing Hospital The Fourth Military Medical University Xi'an, China

${ }^{4}$ Department of Prosthetics Stomatological Hospital The Fourth Military Medical University Xi'an, China

Correspondence: JJ Harding Nuffield Laboratory of Ophthalmology University of Oxford Walton Street Oxford OX2 6AW, UK Tel: + 441865248996 +44 1865723485 Fax: + 441865794508 E-mail: john.harding@ eye.ox.ac.uk

Received: 27 June 2002 Accepted in revised form: 7 October 2002 
$\beta$-crystallin is degraded in the selenite cataract. ${ }^{16,17}$ Limited proteolysis of crystallins, especially $\beta$-crystallin polypeptides, leads to loss of the $\mathrm{N}$-terminal extensions on $\beta$-crystallins, abnormal interaction of crystallins, insolubilisation of proteolyzed $\beta$ - and $\alpha$-crystallins, coprecipitation of $\gamma$-crystallins, and loss of cytoskeletal proteins and soluble proteins. ${ }^{18,19}$

Mainly $\beta$-crystallins are precipitated, but there is concurrent calpain-induced proteolysis of $\alpha$-crystallins, which leads to a marked reduction in $\alpha$-crystallin chaperone activity in selenite nuclear cataract ${ }^{20}$ and Shumiya cataract ${ }^{21}$ in rat. $\alpha$-Crystallin has chaperone-like properties, being capable of binding to unfolded or denatured proteins and suppressing nonspecific aggregation..$^{22}$ The chaperone function of $\alpha$-crystallin helps to prevent the formation of large light-scattering aggregates, inactivation of enzymes, and possibly cataract. ${ }^{23,24}$

Different assays for chaperone function of $\alpha$-crystallin have been developed including heat- and UV-induced protein aggregation, sugar, and steroid inactivation of enzymes. ${ }^{23,25}$ Kelley et $a l^{20}$ showed that the chaperone activity of $\alpha$-crystallin from the nucleus of rat lenses was diminished in selenite cataract, but their only chaperone assay was a $\beta_{\mathrm{L}}$-crystallin aggregation assay at $64^{\circ} \mathrm{C}$, far from physiological temperatures. Assays at physiological temperature are to be preferred. Some studies of mutant $\alpha$-crystallins have led to confusion because they showed no chaperone function at elevated temperatures simply because the proteins were less stable than wild type. $^{26}$

Catalase is a crucial antioxidative enzyme in the normal lens. ${ }^{27}$ Its activity decreased with ageing and in human cataract. ${ }^{28,29}$ The evaluation of chaperone activity of $\alpha$-crystallin using catalase assays has been established by our group including thermal aggregation of catalase, inactivation of catalase by fructose, ${ }^{30}$ steroid, ${ }^{31}$ and thermal stress. ${ }^{32} \alpha$-Crystallin can protect catalase activity against thermal or glycation-induced inactivation and aggregation on the denaturation pathway, but it shows different abilities to promote functional refolding by preventing proteins from misfolding or entering kinetic traps on the renaturation pathway. ${ }^{31,32}$

Incubation of cultured rat lenses with $0.2 \mathrm{mM}$ selenite for $24 \mathrm{~h}$, resulted in an increase in selenium content and lens opacity. ${ }^{33}$ However, the exact role of the chaperone function provided by $\alpha$-crystallin in the pathogenicity of selenite cataract remains to be elucidated.

The purpose of this study was to investigate the molecular chaperone activity of $\alpha$-crystallin in normal and selenite-induced cataractous lenses using four different assays including thermal aggregation assays of catalase and of $\beta_{\mathrm{L}}$-crystallin, and catalase inactivation assays by glycation and by heat. The chaperone activities of both HMW and $\alpha_{\mathrm{L}}$-crystallin from completely cataractous lenses were also measured compared with normal lenses. The cataract included both cortical and nuclear regions in contrast with most previous studies, which have been on pure nuclear cataract. The effect of sodium selenite on chaperone activity of $\alpha$-crystallin was further investigated in vitro and its possible aggregation was assessed by high-performance liquid chromatography HPLC. The different assays demonstrated a similar pattern of results. The observations in vitro reinforce evidence that chaperone function may contribute to the development of aggregated proteins in the selenite cataract formation, and showed that selenite can directly cause aggregation of $\alpha$-crystallin and loss of its chaperone function.

\section{Materials and methods}

\section{Materials}

The catalase from bovine liver (EC 1.11.1.6), fructose, bovine serum albumin, lysozyme, and SDS were purchased from Sigma Chemical Co (Beijing, China). Sephacryl S-300HR was from Pharmacia Ltd (Beijing, China). Sodium selenite was from Merck (Lutterworth, UK). BioSep-SEC-S4000 was obtained from Phenomenex (Macclesfield, UK).

\section{Animals}

Seven litters of Sprague-Dawley rats at 8-10 days postpartum were provided by Animal Laboratories (Xi'an, China), and were housed in individual polypropylene breeding cages under a day/night cycle of $12 \mathrm{~h}$, at $25^{\circ} \mathrm{C}$ room temperature, and with both the male and female parents present throughout weaning. The rats received laboratory chow and distilled water ad libitum. The rat experiment conformed to accepted principles of animal maintenance and care.

Half the pups of each litter were daily given subcutaneous injections of $20 \mu \mathrm{mol}$ sodium selenite $/ \mathrm{kg}$ body weight in $0.9 \% \mathrm{NaCl}$ in the scruff of the neck starting at 8-10 days postpartum and served as the cataract group, while the remaining pups of each litter were injected with saline over 5 days and served as the control.

When the eyelids opened at 13-15 days postpartum, eyes were dilated with $0.5 \%$ atropine sulphate (Atropine, Alcon) and examined with a slit lamp (Zeiss). After 20 days of injections, 74 both cortical and nuclear cataractous and 80 clear lenses were removed immediately after decapitation of the rats. 


\section{Isolation of crystallins}

The $\alpha$-crystallin was isolated from rat lens by size-exclusion gel chromatography on Sephacryl S-300HR as described by Slingsby and Bateman, ${ }^{34}$ and Derham and Harding. ${ }^{35}$ Bovine $\alpha_{\mathrm{L}}$-crystallin and $\beta_{\mathrm{L}}$-crystallin were separated by the same method. Decapsulated lenses were weighed and homogenised in seven times their mass of $0.05 \mathrm{M}$ sodium phosphate buffer, $\mathrm{pH}$ 6.7. The homogenates were centrifuged at $22440 \mathrm{~g}$ for $40 \mathrm{~min}$ at $4{ }^{\circ} \mathrm{C}$ to separate the soluble and insoluble lens proteins. The supernatants were loaded onto the chromatography column $\left(1.6 \times 100 \mathrm{~cm}^{2}\right)$ and proteins eluted using the same buffer at a flow rate of $18 \mathrm{ml} / \mathrm{h}$. The fractions corresponding to each standard peak as $\alpha$-high and $\alpha$-low in rats or $\beta$-low in bovine lenses were pooled separately, dialysed against at least three changes of distilled water over $24 \mathrm{~h}$ at $4{ }^{\circ} \mathrm{C}$. The pooled fractions were separately freeze-dried, and stored at $-20^{\circ} \mathrm{C}$ until required. The purity of $\alpha$-crystallin was confirmed by SDS-PAGE electrophoresis.

\section{Incubation of bovine $\alpha_{L}$-crystallin with sodium selenite}

Bovine $\alpha_{\mathrm{L}}$-crystallin, $30 \mathrm{mg}$, was dissolved in $15 \mathrm{ml}$ sodium selenite, over a concentration range of $0,0.4,4$, 10,50 , and $100 \mathrm{mM}$. The solution was then filtered through a sterilised $0.2 \mu \mathrm{m}$ pore-sized sterilized Millipore filter into a sterilized $30 \mathrm{ml}$ glass vial with silicone bung and incubated at $37^{\circ} \mathrm{C}$ in a shaking water bath. At time zero, 24, and $72 \mathrm{~h}, 3 \mathrm{ml}$ samples were individually removed from each of the solutions by syringe and then were dialysed in microdialysis tubing with a minimum of three changes of 51 of distilled water over $24 \mathrm{~h}$. After freeze-drying, the chaperone activity of $\alpha$-crystallin was determined using the $\beta_{\mathrm{L}}$-crystallin aggregation assay and further analysed by HPLC.

\section{HPLC analysis}

HPLC was carried out using a Gilson 714 HPLC equipped with a BioSep-SEC-S4000 $\left(300 \times 7.8 \mathrm{~mm}^{2}\right)$ size-exclusion column. Protein samples of $0.5 \mathrm{ml}$ were taken from incubation experiments at $24 \mathrm{~h}$. They were then centrifuged at $2800 \mathrm{~g}$ for $5 \mathrm{~min}$ before being injected on to the column (up to $50 \mu \mathrm{l}$ ). All analyses were performed at ambient temperature and eluted with $0.1 \mathrm{M}$ sodium phosphate buffer $(\mathrm{pH}$ 6.9) at a flow rate of $1 \mathrm{ml} /$ min. Protein elution was monitored at $280 \mathrm{~nm}$.

\section{Aggregation assays}

The heat aggregation assays were based on those described by Derham and Harding ${ }^{35,36}$ and Hook and
Harding $^{31}$ with slight modifications. The ratio of $1: 2.5$ (w/w) corresponding to $100 \mu \mathrm{g}$ of $\alpha$-crystallin to $250 \mu \mathrm{g}$ target proteins $\left(\beta_{\mathrm{L}}\right.$-crystallin and catalase) was used for chaperone assays. Lysozyme and bovine serum albumin were examined in every experiment as controls substituting for the $\alpha$-crystallin. The scattering resulting from aggregation at $60^{\circ} \mathrm{C}$ was measured for $60 \mathrm{~min}$ at $360 \mathrm{~nm}$ in a Kontron 930 spectrophotometer as an index of turbidity. All assays were repeated in triplicate. Chaperone activity was determined as a percentage of protection relative to the target protein control after $60 \mathrm{~min}$.

\section{Sugar-induced inactivation assay}

The enzyme inactivation assay by sugar was based on that described by Hook and Harding. ${ }^{31,32} \alpha$-Crystallin was present at $40 \mu \mathrm{g} / \mathrm{ml}$ in a solution containing catalase $(525 \mathrm{IU}, 25 \mu \mathrm{g} / \mathrm{ml})$ and $5 \mathrm{mM}$ fructose. Catalase activity was assayed at 2-day intervals over 6 days incubation in a shaking water at $37^{\circ} \mathrm{C}$.

\section{Inactivation assay by heat}

Catalase (525 IU, $25 \mu \mathrm{g} / \mathrm{ml}$ ) was incubated at $60^{\circ} \mathrm{C}$ with and without $40 \mu \mathrm{g} / \mathrm{ml} \alpha$-crystallin, bovine serum albumin, or lysozyme for $40 \mathrm{~min}$ in a final volume of $1 \mathrm{ml}$. Activity was assayed at $10 \mathrm{~min}$ intervals. Chaperone ability was represented as a percentage of activity remaining at the end of incubation compared to the corresponding $\alpha$-crystallin incubation.

\section{Catalase assay}

The assay of catalase activity was performed at $37^{\circ} \mathrm{C}$ as described previously by monitoring the decreased absorbance at $240 \mathrm{~nm}$ resulting from the decomposition of hydrogen peroxide for $1 \mathrm{~min}$ in a reaction mixture ( $3 \mathrm{ml}$ final volume) containing $2.98 \mathrm{ml}$ of solution from diluted $30 \%(\mathrm{w} / \mathrm{v}) \mathrm{H}_{2} \mathrm{O}_{2}$ and $20 \mu \mathrm{l}$ incubation solution in $50 \mathrm{mM}$ sodium phosphate buffer, $\mathrm{pH} 7 .{ }^{37}$ All assays were carried out in triplicate. Activity is expressed relative to the control activity at each respective time interval, set at $100 \%$.

\section{SDS-PAGE}

SDS-polyacrylamide gel electrophoresis of proteins was based on Laemmli's system under reducing conditions ${ }^{38}$ by using Electrophoresis Units (Bio-RAD) on composite gels consisting of a 5\% stacking gel and a $12.5 \%$ resolving gel. The gel was stained by Coomassie blue R-250. 


\section{Analysis}

The statistical significance of differences were assessed with Student's $t$-test using SPSS (Version 10.0) software. Where error bars are displayed on graphs, these represent standard deviations of three individual experiment from each group.

\section{Results}

\section{Incidence of cataract}

Six days after injection, the incidence of nuclear cataract was $90 \%(70 / 78)$, and cortical plus nuclear cataract was $6 \%(5 / 78)$. The frequency of complete opacification of the lenses had risen to $95 \%$ (74/78) 20 days after injections started (Table 1).

In a preliminary experiment, the ineffectiveness of selenite after 15-20 days postpartum was found in 10 rats even though an increased amount of sodium selenite ( $60 \mathrm{~mol} / \mathrm{kg}$ body weight) was injected (results not shown).

\section{Isolation of lens crystallins}

The elution profile from clear and cataractous lenses of soluble proteins showed an increase of the $\alpha_{\mathrm{H}}$-crystallin peak and a slight decrease of both $\beta_{\mathrm{H}^{-}}$and $\beta_{\mathrm{L}}$-crystallin peaks in selenite cataract lenses, while the $\gamma$-fraction appeared to be unaffected (Figure 1). The fractions of $\alpha_{\mathrm{H}^{-}}$and $\alpha_{\mathrm{L}}$-crystallin contained approximately 39 and $61 \%$ of total $\alpha$-crystallin, respectively, in clear lenses as assessed by the elution profile on Sephacryl S-300HR. However, the percentage of $\alpha_{\mathrm{H}^{-}}$and $\alpha_{\mathrm{L}}$-crystallin changed to 49 and $51 \%$ of total $\alpha$-crystallin in selenite cataract lenses. Both $\alpha_{\mathrm{H}^{-}}$and $\alpha_{\mathrm{L}}$-crystallin from control and cataractous lenses were further analysed by SDS-PAGE (Figure 2). The $\alpha_{\mathrm{H}^{-}}$-crystallin from cataractous lenses contained a few new polypeptides below $20 \mathrm{kDa}$. New 25 and $23 \mathrm{kDa}$ bands were also present in $\alpha_{\mathrm{H}^{-}}$and $\alpha_{\mathrm{L}}$-crystallin. These changes were previously reported in nucleus of the pure nuclear cataract model. ${ }^{16}$

\section{Chaperone activity of $\alpha$-crystallin assessed using four different assays}

Protection by $\alpha$-crystallin against heat-induced aggregation of catalase and $\beta_{\mathrm{L}}$-crystallin, and fructationand heat-induced inactivation of catalase are shown (Figure 3a-d). The pattern of the protective effect in both

Table 1 The incidence of cataract induced by five subcutaneous injections of sodium selenite in young Sprague-Dawley rats over a 20-day period starting at 8-10 days postpartum

\begin{tabular}{|c|c|c|c|c|c|c|c|c|}
\hline \multirow[t]{2}{*}{ Group } & \multirow[t]{2}{*}{ Number (rats) } & \multirow[t]{2}{*}{ Cataract } & \multicolumn{6}{|c|}{ Clear or cataractous lenses after injection } \\
\hline & & & 3 days & 6 days & 9 days & 12 days & 15 days & 20 days \\
\hline $\mathrm{C}$ & 40 & - & 80 & 80 & 80 & 80 & 80 & 80 \\
\hline \multirow[t]{3}{*}{ S } & 39 & - & 22 & 3 & 0 & 0 & 0 & 0 \\
\hline & & + & 56 & 70 & 36 & 20 & 16 & 4 \\
\hline & & $*$ & 0 & 5 & 42 & 58 & 62 & 74 \\
\hline
\end{tabular}

C: control; S: selenite-treated; -: clear lens; +: pure nuclear cataract lens. *: Combined cortical and nuclear cataract lens.

a

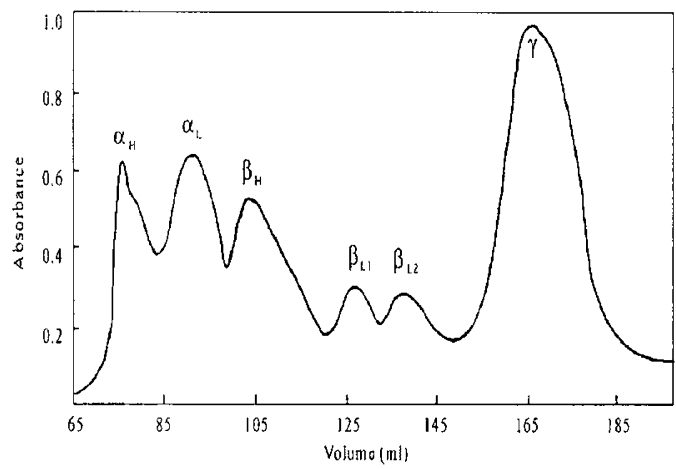

b

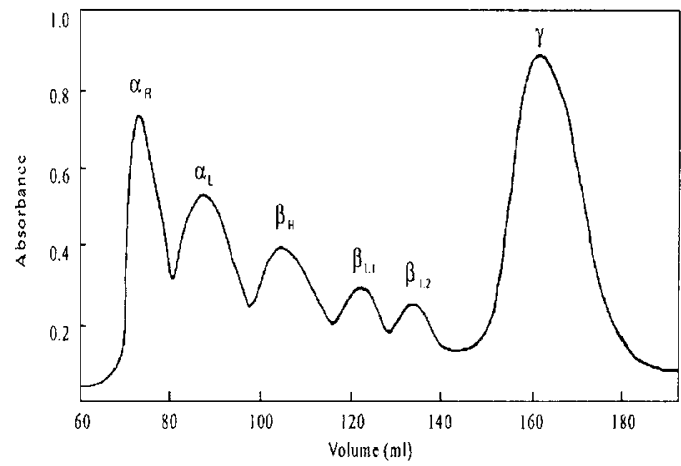

Figure 1 Elution profiles from size-exclusion chromatography using Sephacryl S-300HR of water-soluble proteins from clear and selenite-induced cataract lens in rats. (a) Clear lens. (b) Selenite-induced cataract lens. The $\alpha_{\mathrm{H}}, \alpha_{\mathrm{L}}, \beta_{\mathrm{H}}, \beta_{\mathrm{L}}$, and $\gamma$ represent the corresponding crystallin elution peaks. 


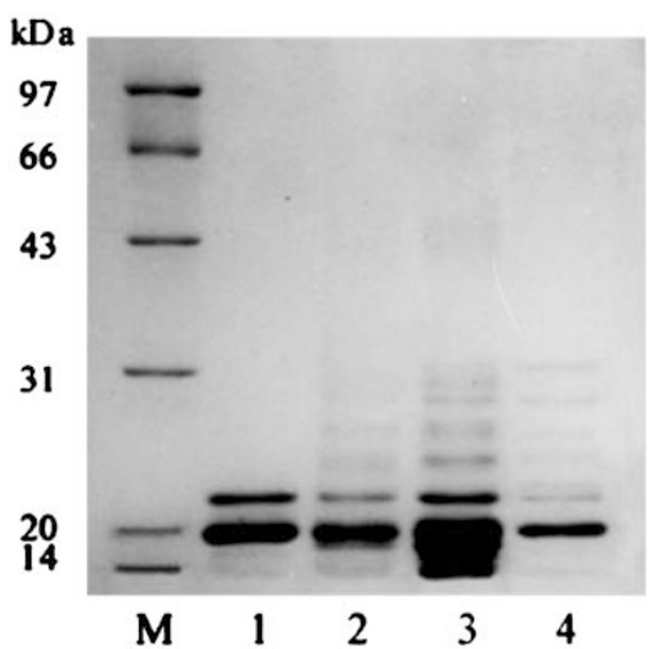

Figure 2 SDS-PAGE analysis of $\alpha$-high and $\alpha$-low crystallin preparations from clear and selenite-induced cataract lenses in rats. Lane $\mathrm{M}$, molecular weight standards labelled in the margin in kilo Daltons; lanes 1 and 2, $\alpha$-low and $\alpha$-high from clear lens; lanes 3 and $4, \alpha$-high and $\alpha$-low from selenite-induced cataract lens, respectively. Note the appearance of proteolytic fragments below the $20 \mathrm{kDa}$ band in lane 3 .

$\alpha_{\mathrm{H}^{-}}$and $\alpha_{\mathrm{L}}$-crystallin is very similar. The protection of $\alpha_{\mathrm{H}^{-}}$-crystallin from normal and cataractous lenses was approximately $28.7 \%(P<0.001)$ and $23.7 \%(P<0.001)$ less than that of $\alpha_{\mathrm{L}}$-crystallin with the catalase aggregation assay (Figure 3a), 10.9\% $(P=0.028)$ and $13.4 \%(P=0.022)$ with the $\beta_{\mathrm{L}}$-crystallin aggregation assay (Figure $3 b), 8 \%(P=0.032)$ and $5.7 \%(P=0.142)$ with the fructation inactivation assay (Figure 3c), 5\% $(P=0.146)$ and $2.1 \%(P=0.263)$ with the heat inactivation assay (Figure $3 \mathrm{~d}$ ), respectively.

The chaperone activities of $\alpha_{\mathrm{H}^{-}}$and $\alpha_{\mathrm{L}}$-crystallin in selenite cataract were diminished approximately $14.7 \%$ $(P<0.001)$ and $19.7 \%(P<0.001)$ according to the catalase aggregation assay (Figure 3a), $8.5 \%(P=0.001)$ and $6 \%$ $(P=0.047)$ by the $\beta_{\mathrm{L}}$-crystallin aggregation assay (Figure 3b), $14 \%(P<0.001)$ and $16.3 \%(P<0.001)$ by the glycation inactivation assay (Figure $3 \mathrm{c}$ ), and $7 \%(P=0.008)$ and $10 \%(P=0.003)$ by thermal inactivation assay (Figure $3 \mathrm{~d}$ ) compared with normal lenses, respectively. $\alpha$-Crystallin was more effective in preventing the thermal aggregation of catalase than of $\beta_{\mathrm{L}}$-crystallin. The control proteins, lysozyme and serum albumin, displayed no such protective ability when substituted for $\alpha$-crystallin (results not shown).

Fructose inactivated catalase in a progressive manner during 6 days incubation. In the presence of $5 \mathrm{mM}$ fructose, catalase activity fell to 15 and $6 \%$ after 4 and 6 days, respectively; but with $\alpha$-crystallin from clear and cataractous lenses, activity remained at $50-70 \%$ and fell to $35-60 \%$ after the same time periods, respectively. Clearly, $\alpha$-crystallin could partly protect against inactivation by $5 \mathrm{mM}$ fructose for a limited period of time. There was a subunit protection ratio of $5: 1$ $(\alpha$-crystallin : catalase) or each molecule of $\alpha$-crystallin protected two molecules of catalase, assuming the $\alpha$-crystallin exits as a complex of $800 \mathrm{kDa}$.

Protection by $\alpha$-crystallin against thermal inactivation of catalase appeared to be conferring 13-18 and $5-9 \%$ protection in clear and cataractous lenses, respectively, after $40 \mathrm{~min}$ (Figure $3 \mathrm{~d}$ ). $\alpha$-Crystallin conferred statistically significant, but not full, protection against catalase thermal inactivation at $60^{\circ} \mathrm{C}$ in the same protection ratio as above. It showed a much less efficient protection against the thermally induced inactivation of catalase at $60^{\circ} \mathrm{C}$ than it did against fructose-induced inactivation at $37^{\circ} \mathrm{C}$, emphasising the importance of chaperone assays at physiological temperatures.

\section{Chaperone activity of $\alpha$-crystallin with selenite-treated and HPLC analysis}

The effect of sodium selenite on chaperone activity of bovine $\alpha_{\mathrm{L}}$-crystallin is shown in Figure 4 . The chaperone activity was significantly decreased after $24 \mathrm{~h}$ incubation with 10,50 , and $100 \mathrm{mM}$ sodium selenite in comparison with the control group. There was no further falling in chaperone activity after $72 \mathrm{~h}$ incubation (results not shown).

$\alpha_{\mathrm{L}}$-Crystallin was subject to HPLC analysis after treatment with various selenite concentrations (Figure 5). Curve a was the gel filtration profile of normal $\alpha_{\mathrm{L}^{-}}$ crystallin without selenite-treatment as a reference; no aggregate peak was observed. Incubation at $37^{\circ} \mathrm{C}$ did not cause aggregation of normal $\alpha_{\mathrm{L}}$-crystallin (Figure $5 \mathrm{a}, \mathrm{b}$ ). There was an unambiguous formation of aggregates after incubation with selenite for $24 \mathrm{~h}$, the amount of which gradually increased as shown from curves $\mathrm{c}$ to $\mathrm{f}$. The peak of $\alpha_{\mathrm{L}}$-crystallin decreased and shifted to the high molecular weight at least up to $50 \mathrm{mM}$ selenite.

Equivalent amounts of $\alpha$-crystallin were noted in curves $\mathrm{c}-\mathrm{f}$, suggesting that the aggregated form consists mostly of $\alpha$-crystallin itself. These data are consistent with the reduction of its chaperone activity, indicating that selenite induced the aggregation of $\alpha$-crystallin in a dose-dependent manner. This in turn showed that the decreased chaperone activity in selenite cataract may contribute to aggregation in cataract formation. The maximum effect on both chaperone activity (Figure 4 ) and aggregation (Figure 5) was at $50 \mathrm{mM}$ sodium selenite. 


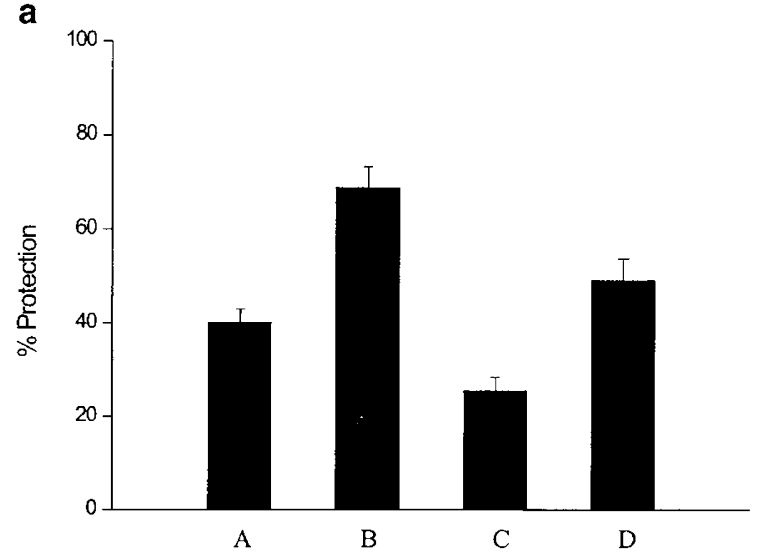

C

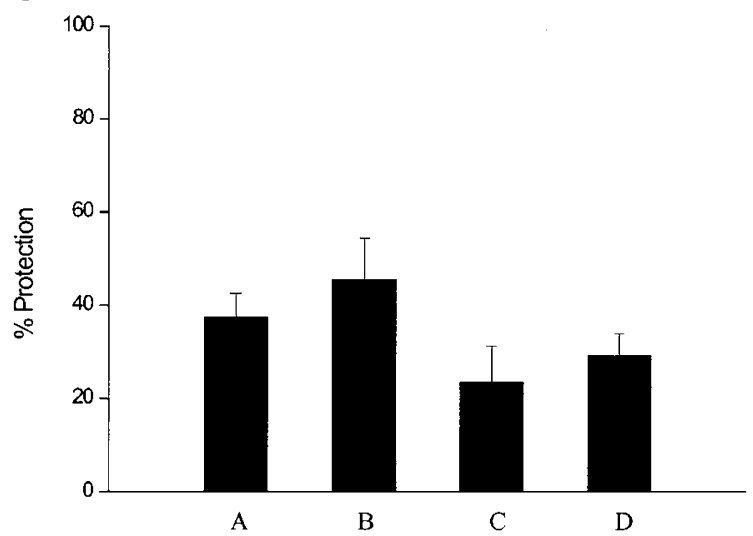

b

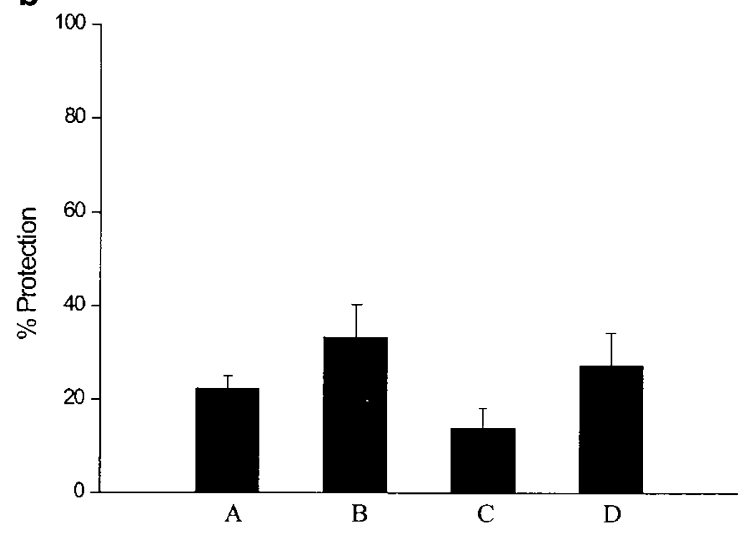

d

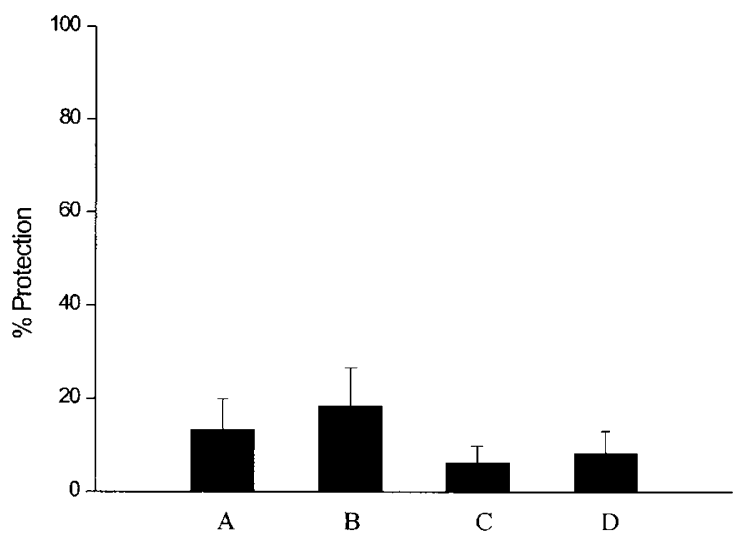

Figure 3 Chaperone activity of rat $\alpha_{\mathrm{H}^{-}}$and $\alpha_{\mathrm{L}}$-crystallins from clear and selenite-induced cataract lens. Chaperone activity is represented as a percentage of protection relative to the target proteins in aggregation assays and as a percentage of activity remaining in inactivation assays. Each data point is represented as the mean $\pm \mathrm{SD}$ of three readings in each segment. $\mathrm{A}, \alpha_{\mathrm{H}^{-}}$-crystallin from clear lens; $B, \alpha_{\mathrm{L}}$-crystallin from clear lens; $\mathrm{C}, \alpha_{\mathrm{H}}$-crystallin from selenite-induced cataract lens; $\mathrm{D}, \alpha_{\mathrm{L}}$-crystallin from selenite-induced cataract lens. (a) Protection against heat-induced aggregation of catalase $(250 \mu \mathrm{g})$ at $60^{\circ} \mathrm{C}$ by $\alpha_{\mathrm{H}^{-}}$and $\alpha_{\mathrm{L}}$-crystallins $(100 \mu \mathrm{g})$ from clear and selenite-induced cataract lens in rats. Chaperone activity was represented as a percentage protection relative to the catalase control after $60 \mathrm{~min}$. (b) Protection against heat-induced aggregation of $\beta_{\mathrm{L}}$-crystallin $(250 \mu \mathrm{g})$ at $60^{\circ} \mathrm{C}$ by $\alpha_{\mathrm{H}^{-}}$and $\alpha_{\mathrm{L}}$-crystallins $(100 \mu \mathrm{g})$ from clear and selenite-induced cataract lenses in rats. Chaperone activity was represented as a percentage protection relative to the $\beta_{\mathrm{L}}$ crystallin control after $60 \mathrm{~min}$. (c) Protection of enzyme activity following fructation $(5 \mathrm{mM})$ of catalase $(25 \mu \mathrm{g} / \mathrm{ml})$ at $37^{\circ} \mathrm{C}$ by $\alpha_{\mathrm{H}^{-}}$and $\alpha_{\mathrm{L}}$-crystallins $(40 \mu \mathrm{g} / \mathrm{ml})$ from clear and selenite-induced cataract lens in rats. Protection was obtained as a percentage of activity remaining compared to an enzyme only at 6 days incubation. (d) Protection of enzyme activity following thermal inactivation of catalase $(25 \mu \mathrm{g} / \mathrm{ml})$ at $60^{\circ} \mathrm{C}$ by $\alpha_{\mathrm{H}}$ and $\alpha_{\mathrm{L}}$-crystallins $(40 \mu \mathrm{g} / \mathrm{ml})$ from clear and selenite-induced cataract lenses in rats. Protection was obtained as a percentage of activity remaining compared to a control with enzyme alone after 40 min incubation.

\section{Discussion}

Selenite is cataractogenic only when administered to young rats before completion of the critical maturation period of the lens (approximately 16 days of age). ${ }^{2}$ The timing of injection is very critical possibly because of the sharply decreasing uptake of selenium by the lens. ${ }^{39}$ Severe cortical cataract, in addition to the nuclear cataract previously characterised, develops in lenses approximately 15-30 days after a single injection of selenite. By $25-35$ days, $77 \%$ of the selenite-injected rats developed cortical cataract although they subsequently became clear after 4 months. ${ }^{10}$ Our results showed that both cortical and nuclear cataracts were present in $94 \%$ of rats after five subcutaneous injections of sodium selenite over a 20-day period, and in $70 \%$ of the rats dense nuclear opacity appeared by 3 days after the last injection. It is suggested that, given the overdose of selenite in Sprague-Dawley rats, it is possible to shorten the timing of the appearance of the total cataract formation.

The present results showed an increase of the $\alpha_{\mathrm{H}}$-crystallin and decrease of the $\alpha_{\mathrm{L}}$-crystallin in cataractous lenses compared with clear lenses. Both 


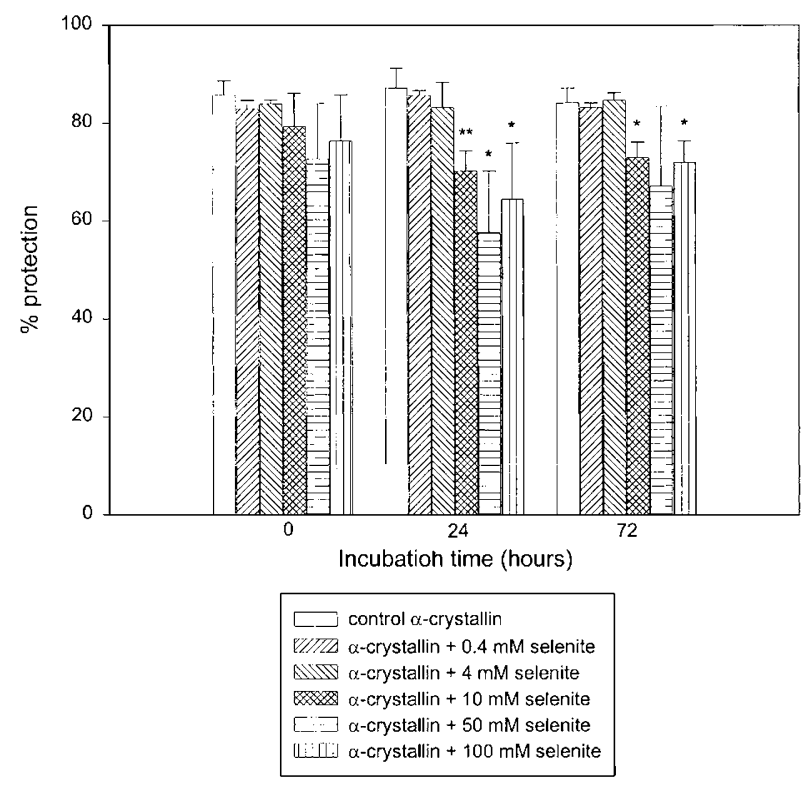

Figure 4 Effect of sodium selenite on the chaperone activity of bovine $\alpha_{\mathrm{L}}$-crystallin as assessed by the $\beta_{\mathrm{L}}$-crystallin aggregation assay. Protection was obtained as a percentage of protection relative to the $\beta_{\mathrm{L}}$-crystallin control at 0,24 , and $72 \mathrm{~h}$ incubation. Each point represents the mean of three measurements. ${ }^{*} P<0.05$ and ${ }^{* * P}<0.01$ are the levels of significance. Data are presented as mean \pm SD.

$\alpha_{\mathrm{H}^{-}}$and $\alpha_{\mathrm{L}}$-crystallin preparations from the completely cataractous lenses contained a few new bands, which corresponded in size to several $\beta_{\mathrm{H}^{-}}$and $\beta_{\mathrm{L}}$ polypeptides. This is consistent with the earlier report on nuclear cataract after a single injection of selenite in 10-day-old rats ${ }^{16}$ which indicated that proteolysis had resulted in a

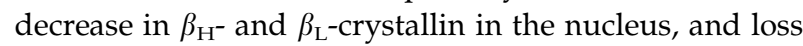
of many polypeptides from the soluble, insoluble, and intrinsic membrane fractions. Isolated cortical crystallins showed no significant changes in polypeptide composition following selenite cataract formation, ${ }^{10,20}$ which is surprising given that calpain activity is found in lens cortex, but not in nucleus. ${ }^{40}$ Truncated proteins have been identified in lens, therefore proteolysis of lens proteins may play a role in cataract formation. ${ }^{41}$ Activation of the cysteine protease calpain II may be responsible for decreased chaperone activity in selenite cataract.

Different assays of chaperone function at physiological and at elevated temperatures exhibited similar patterns of protection in the present study. However, the protective effect against inactivation of catalase by glycation at $37^{\circ} \mathrm{C}$ was much greater than that by heat at $60^{\circ} \mathrm{C}$. Glycation probably inactivates catalase by conformational changes of the enzyme and the protective effect of $\alpha$-crystallin is probably by stabilising the native structure. The thermally induced conformational change to the target proteins leads to noncovalent binding to $\alpha$-crystallin, which binds hydrophobic regions revealed by unfolding target proteins with the generation of soluble complexes. The cumulative evidence of the protection of $\alpha$-crystallin against inactivation of all enzymes investigated and thermal aggregation of enzymes and other proteins suggests the lack of substrate specificity of $\alpha$-crystallin. ${ }^{23,25}$ Previous experiments in ageing and human cataract indicated that posttranslational modification may be responsible for decreases of $\alpha$-crystallin chaperone activity, and it shows a similar pattern by aggregation and inactivation of malate dehyrogenase assays. ${ }^{35,36}$ Sorbitol dehydrogenase was significantly protected from both thermally induced inactivation and aggregation by bovine lens $\alpha$-crystallin. ${ }^{42}$ Our results further support the view that the different assays are measuring essentially the same property, but present quantitatively different protective effects with different methods.

The $\alpha_{\mathrm{H}}$-crystallin showed compromised protection against aggregation and inactivation of proteins in normal and cataractous lenses as reported previously. ${ }^{35,43,44} \alpha_{\mathrm{H}}$-Crystallin has been considered to be an intermediate between the soluble and insoluble fractions, which contained more bound $\beta$ - and $\gamma$-crystallins than $\alpha_{\mathrm{L}}$-crystallin. A decrease in $\alpha_{\mathrm{L}}$-crystallin with an increase in $\alpha_{\mathrm{H}}$-crystallin in selenite lens would lead to a decrease in active $\alpha$-crystallin to provide protection. This may result in reduced suppression of nonspecific aggregation and inactivation of enzymes in cataractous lens. This is in addition to the decreased function of both fractions in the selenite cataract lenses.

In the in vitro study, chaperone activity of selenitetreated bovine $\alpha$-crystallin decreased significantly after $24 \mathrm{~h}$ in a dose-dependent manner. The concentration of sodium selenite used in vitro is higher than that expected in vivo in the rat, but there is more time for modification by selenite to occur in vivo. Chaperone activity of $\alpha$-crystallin in vivo may differ from that determined in vitro. ${ }^{45}$

HPLC analysis showed that the formation of highmolecular-weight aggregates (HMWA) of $\alpha$-crystallin increased with the elevated concentration of selenite, indicating that loss of chaperone activity is concomitant with the formation of HMWA. The decreased chaperone activity of $\alpha$-crystallin resulting from selenite-induced aggregation, and the degradation of lens proteins induced by m-calpain in rat, may combine to promote the aggregation of lens proteins, which could lead eventually to light scatter and cataract. 


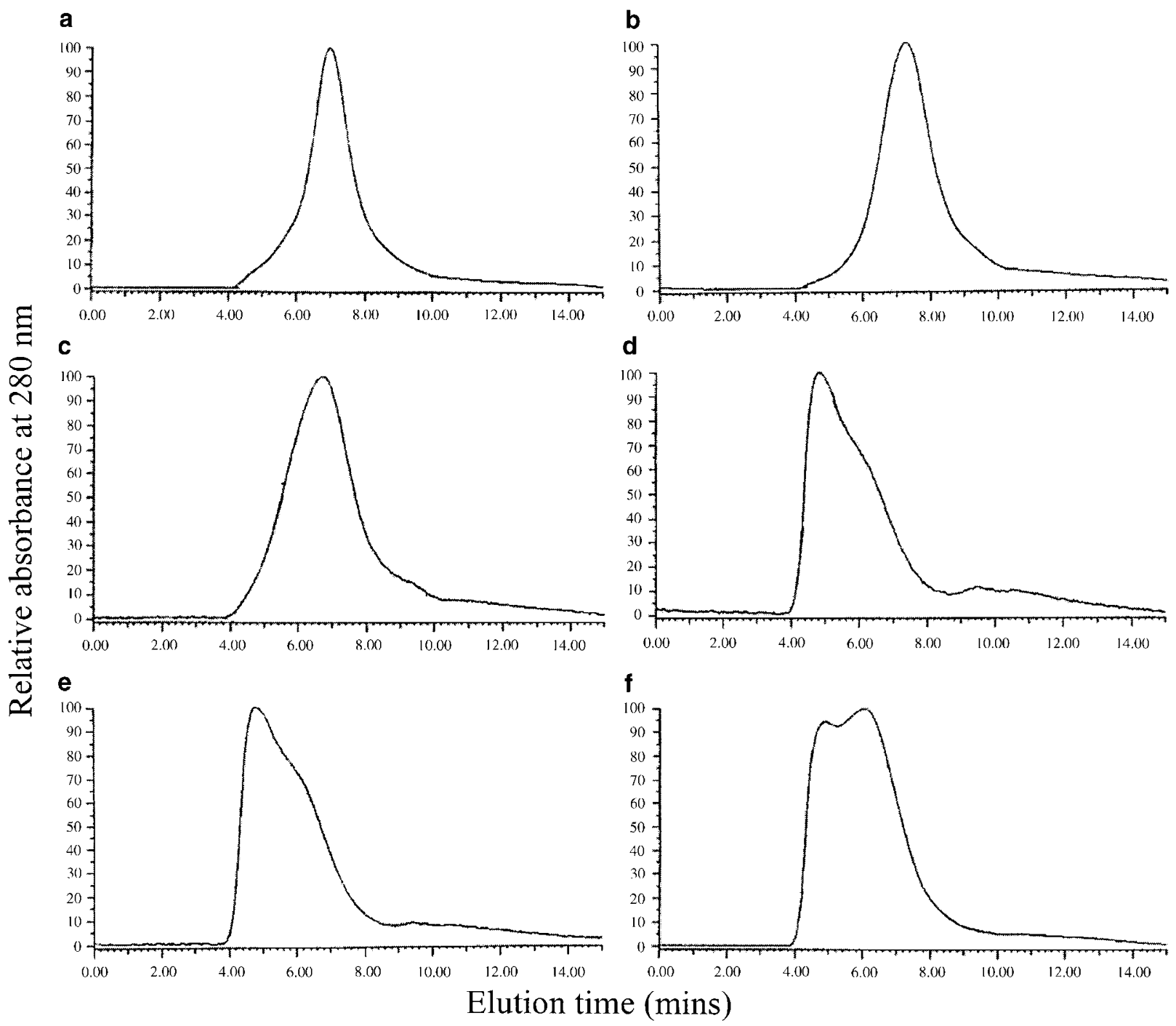

Figure 5 HPLC gel filtration profiles of bovine $\alpha_{\mathrm{L}}$-crystallin after being incubated with various concentrations of sodium selenite for $24 \mathrm{~h}$. Each protein was at a concentration of $0.3 \mathrm{mg} / \mathrm{ml}$. Sodium selenite concentration: (a) normal $\alpha_{\mathrm{L}}$-crystallin without incubation; (b) normal $\alpha_{\mathrm{L}}$-crystallin without selenite treatment after $24 \mathrm{~h}$ incubation; (c) $4 \mathrm{mM}$; (d) $10 \mathrm{mM}$; (e) $50 \mathrm{mM}$; (f) $100 \mathrm{mM}$ sodium selenite.

\section{Acknowledgements}

The studies were presented orally at the annual meeting of the European Association for Vision and Eye Research (EVER), Alicante, Spain, October 2001. The authors would like to acknowledge Akbar Z Shyadehi and Barry K Derham for their guidance with the HPLC analysis and aggregation assay. The studies were supported in part by the Wellcome Trust.

\section{References}

1 Hiraoka T, Clark JI, Li XY, Thurston GM. Effect of selected anti-cataract agents on opacification in the selenite cataract model. Exp Eye Res 1996; 62: 11-19.
2 Shearer TR, Ma H, Fukiage C, Azuma M. Selenite nuclear cataract: review of the model. Mol Vis 1997; 3: $8-16$.

3 Shearer TR, Ma H, Shih M, Hata I, Fukiage C, Nakamura Y et al. Lp82 calpain during rat lens maturation and cataract formation. Curr Eye Res 1998; 17: 1037-1043.

4 Blunt DS, Takemoto L. Inhibition of selenite cataract by S-diethylsuccinyl glutathione isopropyl ester. Curr Eye Res 2000; 20: 341-345.

5 Yilmaz G, Turan B, Celebi N, Yilmaz N, Demirel YE. Prevention of selenite-induced opacification and biochemical changes in the rat pup lens through amiloride pre-treatment. Curr Eye Res 2000; 20: 454-461.

6 Tamada Y, Fukiage C, Mizutani K, Yamaguchi M, Nakamura Y, Azuma M et al. Calpain inhibitor, SJA6017, reduces the rate of formation of selenite cataract in rats. Curr Eye Res 2001; 22: 280-285. 
7 Ostadalova I, Babicky A, Obenberger J. Cataract induced by administration of a single dose of sodium selenite to suckling rats. Experientia 1978; 34: 222-223.

8 Bunce GE, Hess JL. Biochemical changes associated with selenite-induced cataract in the rat. Exp Eye Res 1981; 33: 505-514.

9 Shearer TR, Anderson RS, Britton JL, Palmer EA. Early development of selenium-induced cataract: slit lamp evaluation. Exp Eye Res 1983; 36: 781-788.

10 Anderson RS, Shearer TR, Claycomb CK. Selenite-induced epithelial damage and cortical cataract. Curr Eye Res 1986; 5: 53-61.

11 Schey KL, Fowler JG, Shearer TR, David L. Modification to rat lens major instrinsic protein in selenite-induced cataract. Invest Ophthalmol Vis Sci 1999; 40: 657-667.

12 Huang LL, Zhang CY, Hess JL, Bunce GE. Biochemical changes and cataract formation in lenses from rats receiving multiple, low doses of sodium selenite. Exp Eye Res 1992; 55: 671-678.

13 Shearer TR, Anderson RS, Britton JL. Influence of selenite and fourteen trace elements on cataractogenesis in the rat. Invest Ophthalmol Vis Sci 1983; 24: 417-423.

14 Mitton KP, Hess JI, Bunce GE. Causes of decreased phase transition temperature in selenite cataract model. Invest Ophthalmol Vis Sci 1995; 36: 914-924.

15 Ma H, Fukiage C, Kim YH, Duncan MK, Reed NA, Shih M et al. Characterization and expression of calpain 10. A novel ubiquitous calpain with nuclear localization. J Biol Chem 2001; 276: 28525-28531.

16 David LL, Shearer TR. Calcium-activated proteplysis in the lens nucleus during selenite cataractogenesis. Invest Ophthalmol Vis Sci 1984; 25: 1275-1283.

17 Shearer TR, Shih M, Azuma M, David LL. Precipitation of crystallins from young rat lens by endogenous calpain. Exp Eye Res 1995; 61: 141-150.

18 Matsushima H, David LL, Hiraoka T, Clark JI. Loss of cytoskeletal proteins and lens cell opacification in the selenite cataract model. Exp Eye Res 1997; 64 387-395.

19 Clark JI, Matsushima H, David LL, Clark JM. Lens cytoskeleton and transparency: a model. Eye 1999; 13: 417-424.

20 Kelley MJ, David LL, Iwasaki N, Wright J, Shearer TR. Alpha-crystallin chaperone activity is reduced by calpain II in vitro and in selenite cataract. J Biol Chem 1993; 268: 18844-18849.

21 Inomata M, Kohji N, Takehana M, Saido TC, Kawashima S, Shumiya S. Evidence for the involvement of calpain in cataractogenesis in Shumiya cataract rat (SCR). Biochim Biophys Acta 1997; 1362: 11-23.

22 Howitz J. $\alpha$-Crystallin can function as a molecular chaperone. Proc Natl Acad Sci USA 1992; 89: 10 449-10 453.

23 Hook DWA, Harding JJ. Protection of enzymes by $\alpha$-crystallin acting as a molecular chaperone. Int J Biol Macromol 1998; 22: 295-306.

24 Horwitz J, Bova MP, Ding LL, Haley DA, Stewart PL. Lens $\alpha$-crystallin: function and structure. Eye 1999; 13: 403-408.

25 Derham BK, Harding JJ. Alpha-crystallin as a molecular chaperone. Prog Retin Eye Res 1999; 18: 463-509.

26 Derham BK, van Boekel MAM, Muchowski PJ, Clark JI, Horwitz J, Hepburne SHW et al. Chaperone function of mutant versions of alphaA- and alphaB-crystallin prepared to pinpoint chaperone binding sites. Eur J Biochem 2001; 268: 713-721.

27 Spector A, Ma W, Wang RR. The aqueous humor is capable of generating and degrading $\mathrm{H}_{2} \mathrm{O}_{2}$. Invest Ophthalmol Vis Sci 1998; 39: 1188-1197.

28 Zigman S, Schultz JB, Schultz M. Measurement of oxygen production by in vitro human and animal lenses with an oxygen electrode. Curr Eye Res 1998; 17: 115-119.

29 Reddan JR, Steiger CA, Dziedzic DC, Gordon SR. The regional difference in the distribution of catalase in the epithelium of the ocular lens. Cell Mol Biol 1996; 43: 209-219.

30 Harding JJ, Yan H. Glycation-induced inactivation and loss of antigenicity of catalase and superoxide dismutase; and protection by alpha-crystallin and aspirin. Exp Eye Res 1998; 67 (Suppl 1): 46.

31 Hook DWA, Harding JJ. Alpha-crystallin acting as a molecular chaperone protects catalase against steroidinduced inactivation. FEBS Lett 1996; 382: 281-284.

32 Hook DWA, Harding JJ. Molecular chaperones protect catalase against thermal stress. Eur J Biochem 1997; 247: 380-385.

33 Ito Y, Cai H, Terao M, Tomohiro M. Preventive effect of diethyldithiocarbamate on selenite-induced opacity in cultured rat lenses. Ophthalmic Res 2001; 33: 52-59.

34 Slingsby C, Bateman OA. Rapid separation of bovine beta-crystallin subunits beta-Bl, beta-B2, beta-B3, beta-A3 and beta-A4. Exp Eye Res 1990; 51: 21-26.

35 Derham BK, Harding JJ. Effect of aging on the chaperone-like function of human a $\alpha$-crystallin assessed by three methods. Biochem J 1997; 328: 763-768.

36 Derham BK, Harding JJ. The effects of ageing on the chaperone-like function of rabbit alpha-crystallin, comparing three methods of assay. Biochim Biophys Acta 1997; 1336: 187-194.

37 Yan H, Harding JJ. Glycation-induced inactivation and loss of antigenicity of catalase and superoxide dismutase. Biochem J 1997; 328: 599-605.

38 Laemmli UK. Cleavage of structural proteins during the assembly of the head of Bacteriophage T4. Nature 1970; 227: 680-685

39 Babicky A, Rychter Z, Kopoldova J, Ostadalova I. Age dependence of selenite uptake in rat eye lenses. Exp Eye Res 1985; 40: 101-103.

40 Yoshida H, Murachi T, Tsukahara I. Distribution of calpain I, calpain II (EC 3.4.22.17) and calpastatin in bovine lens. Invest Ophthalmol Vis Sci 1985; 26: 953-956.

41 Harding JJ. Can drugs or micronutrients prevent cataract. Drug Ageing 2001; 18: 473-486.

42 Marini I, Moschini R, Corso AD, Mura U. Complete protection by $\alpha$-crystallin of lens sorbitol dehydrogenase undergoing thermal stress. J Biol Chem 2000; 275: 32559-32565.

43 Takemoto L, Boyle D. Molecular chaperone properties of the high molecular weight aggregation from aged lens. Curr Eye Res 1994; 13: 35-44.

44 Carver JA, Nicholls KA, Aquilina JA, Truscott RJ. Age-related changes in bovine $\alpha$-crystallin and highmolecular-weight protein. Exp Eye Res 1996; 63: 639-647.

45 Mandal K, Dillon J, Gaillard ER. Heat and concentration effects on the small heat shock protein, alpha-crystallin. Photochem Photobiol 2000; 71: 470-475. 